\title{
Comparative Studies of Biostimulation and Phytoremediation in the Mitigation of Crude Oil Toxicity in Tropical Soil
}

\author{
*TANEE, F. B. G.; KINAKO, P.D.S. \\ Department of Plant Science \& Biotechnology, Faculty of Science. University of Port Harcourt. \\ P.M.B. 5323, Choba. Rivers state, Nigeria. 08035426615
}

\begin{abstract}
Comparative studies of biostimulation using local materials and phytoremediation in the mitigation of crude toxicity on tropical soil of the Niger-Delta of Nigeria were carried out. 5\% pollution level of crude oil were done alongside the control. Remediation treatments were done after one week of pollution using the following materials: Batch A : 20g of NPK 15:15:15; batch B: 50g of poultry dung; batch C: 5 seeds of Vigna unguiculata grown on the polluted soil (phytoremediation); batch D: control (pollution but no remediation); and batch E: double control (no pollution and no remediation treatment). Soil analyses result indicated that the different remediation treatments have potentials to ameliorate crude oil toxicity at different degrees because of their ability to increase the nutrient content and decrease the total hydrocarbon content of the soil. There was no statistical difference in the soil $\mathrm{pH}$, Zinc and Copper contents between and within treatments throughout the study period. Highest crude oil biodegradation and improvement in nutrient content of the soil were observed in NPK 15:15:15 and phytoremediation treatments indicating that these are good remedial treatment options in the mitigation of crude oil toxicity. @ JASEM
\end{abstract}

The Niger Delta ecoregion of Nigeria has been associated with frequent oil spills resulting from oil pipeline vandalization, tanker accidents and accidental rupture of oil pipelines. These mishaps result in the release of crude oil and refined petroleum products into the terrestrial and aquatic environments (Okpokwasili and Amanchukwu, 1988). The intensity of oil damage depends upon a number of abiotic and biotic factors including the season of the spill, type and amount of oil, prevailing weather condition and soil compositions (Alexander \& Webb, 1987; Pezeshki et al., 2000). Despite more stringent environmental regulations, the risk of an oil spill affecting these ecosystems is still high and which we must accept as inevitable (Kinako, 1988; Venosa and Zhu, 2002). For possible elimination of these effects, it is imperative to clean up these pollutants from the environment by applying remedial measures (Ellis et al., 1990).

Bioremediation has emerged as a highly promising secondary treatment option for oil removal since it first application after the 1989 Exxon Valdez spill (Bragg et al., 1994). Several methods are made to crude oil bioremediation. This include biostimulation in which the growth of indigenous oil degraders are stimulated by the addition of nutrients or other growth limiting substrates; Bioaugmentation, in which known oil degrading bacterial are added to supplement the existing microbial population; and phytoremediation, in which the contaminant is degraded by the growth of higher plants. This research attempts to compare the use of biostimulation and phytoremediation using local materials in the mitigation of crude oil toxicity in soil. Such will enable one to identify the best option in the treatment of crude oil contaminant.

\section{MATERIALS AND METHODS}

The experiment was carried out at the University of Port Harcourt Botanic Garden located about 26km North- west of the city of Port Harcourt along the East-west road between Latitude $4.00^{\circ} \mathrm{N}$ and $5.00^{\circ} \mathrm{N}$ and longitude 6.30 and $7.30^{\circ} \mathrm{E}$ in the tropical rainforest belt of Southern Nigeria. The soil in the area is always low in nutrient content due to the leaching of the nutrient down the earth profile by rainfalls which are always very heavy in the area (NLNG, 1995). Surface soil (loamy- clay) was collected from the garden and thoroughly mixed. It was then filled into 35 black polythene bags of diameter $25 \mathrm{~cm}$ and height $17 \mathrm{~cm}$ leaving a space of $6 \mathrm{~cm}$ from the top to give room for the addition of crude oil, remediation materials and water. The sides and bases of the bags were perforated to increase soil aeration and to avoid water logging. The bags were then arranged into 5 batches of 7 replicates each designated as A, B, C, D and E. Batches A-D were polluted with crude oil obtained from Nigeria National Petroleum Corporation, Port Harcourt while $\mathrm{D}$ was not polluted. The crude oil was thoroughly mixed with the soil in the bags. One week after pollution treatment, the different remediation material/ treatments were applied. Batch A was remediated with 20g/bag of NPK 15:15:15 (inorganic fertilizer); B was remediated with $50 \mathrm{~g} / \mathrm{bag}$ of poultry dung (organic fertilizer); $\mathrm{C}$ was phytoremediated with Vigna unguiculata; D received no remediated treatment (control) while E acted as the double control with no pollution and no remediation 
treatment. The remediation treatment were repeated after 8 weeks.

The NPK 15:15:15 was obtained from Agricultural Development Programme, Port Harcourt; the poultry dung from a poultry farm at Bori while the Vigna unguiculata was bought from Mile 1 market, Port Harcourt. Weeding was done on the plots when the need arose. Composite soil samples were taken from batch for soil analyses. Soil sampling started one week after crude oil pollution. This was taken as the 0 week. Subsequent soil samples were taken at every 8 week to determine the physico-chemical parameters. The following soil parameters were analyzed: Soil pH was analyzed using Jennway 3015 $\mathrm{pH}$ Meter. Total organic carbon, phosphorus and Nitrogen were determined by the Oxidation, Ascorbic acid and Kjedahl methods respectively (Stewart et al.,1974). Total hydrocarbon content were analyzed by the Spectrophometric method adapted from Stewart et al., (1974). Zinc and copper were first digested for 15 minutes in electro thermal heater before analysis using atomic absorption spectrophometer. The Carbon- Nitrogen ratio was obtained by dividing the total Carbon by the total Nitrogen for each bag. All data collected were subjected to two-way analysis of variance (ANOVA).

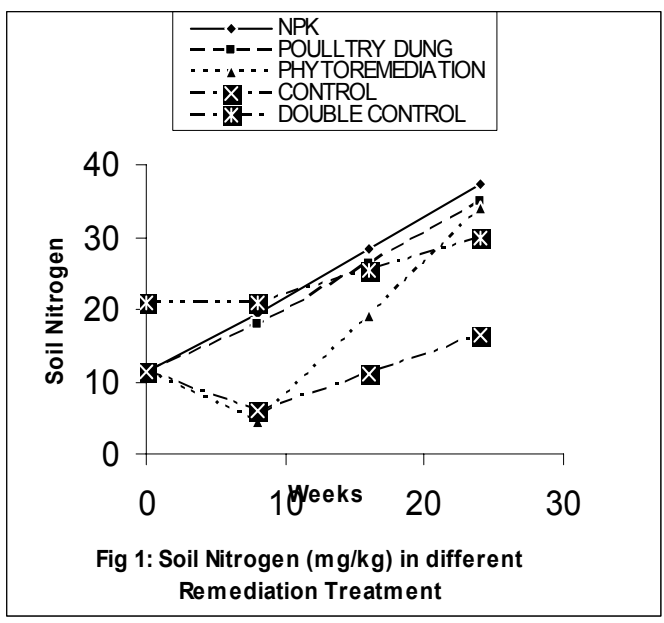

The addition of inorganic fertilizer and the fixation of Nitrogen in the phytoremediation option might have removed the nutrient limitation for microbial activity of biodegradation. It has been reported that addition of Nitrogen and phosphorus enhances biodegradation of polluted soil presumably by removing the Nitrogen and Phosphorus limitation resulting from low natural level (Lee et al., 1993, Odokuma \& Ibor, 2002). High nutrient level stimulated increase in microbial population and activities leading to high energy (carbon) demand by the oil-degrading microbes. This

\section{RESULTS AND DISCUSSION}

The physico-chemical characteristics of the soils in the treatment options are presented in Figs 1-8. As shown in Fig. 1, soil Nitrogen increased significantly between and within treatments with time $(p=0.05)$. At the end of the study period, highest increment in soil Nitrogen were experienced in batch A (11.20 $37.41 \mathrm{mg} / \mathrm{kg})$ and $\mathrm{C}(11.20-33.89 \mathrm{mg} / \mathrm{kg})$. the increase in Nitrogen content in batch A treated with NPK 15:15:15 was as a result of the fact that the fertilizer supplied the Nitrogen (which are always limiting in polluted soil). The increased in the Nitrogen in the phytoremediation treatment (batch C) was as a result of Nitrogen fixation by the Vigna unguiculata (a legume) through the symbiotic association with Rhizobium. Thus the plant (Vigna sp) does not compete with the microorganisms for limited supplies of available Nitrogen at oil contaminated sites rather its increase the soil Nitrogen (Gudin and Syratt, 1975). Phosphate was found to follow a similar pattern as Nitrogen except in the phytoremediation treatment (batch C) which showed a gradual decrease with time as shown in Fig. 2. The reason for the reduction in the phosphate content in this treatment is probably due to the use of the phosphate for growth and development by the introduced plant (Vigna sp) in addition to the one used by the oil-degrading microorganisms.

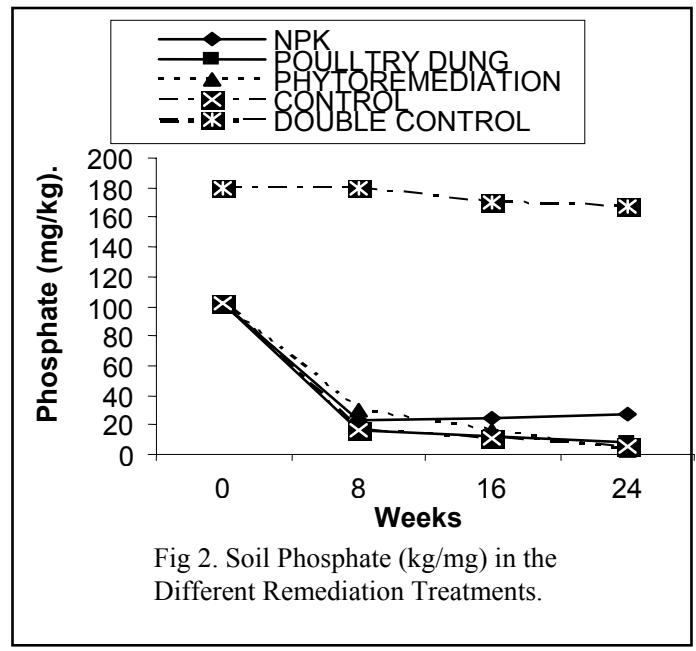

has resulted in the reduction in the total organic carbon (TOC) in the remediation treatments especially in batch A (NPK) and C (phytoremediation) as shown in Fig. 3. This reduction in total organic carbon with time also imply that total hydrocarbon content (THC) loss may have increase with time in these treatments. This is true as shown in Fig. 4 in which THC decreased significantly in the remediated soils than in the control $(p=0.05)$ such that at the end of the study highest loss was evident in the NPK and phytoremediation treatments (675-

* Corresponding author: Tanee, F. B. G. 
$130 \mathrm{mg} / \mathrm{kg}$ ). The higher hydrocarbon loss in the NPK treatment than the poultry dung treatment is in line with Lee et al. (1995) who reported that inorganic fertilizer has greater effect in stimulating crude oil degradation by increasing the total heterotrophic microbial growth and activity. The same applies to the phytoremediation treatment in which in addition
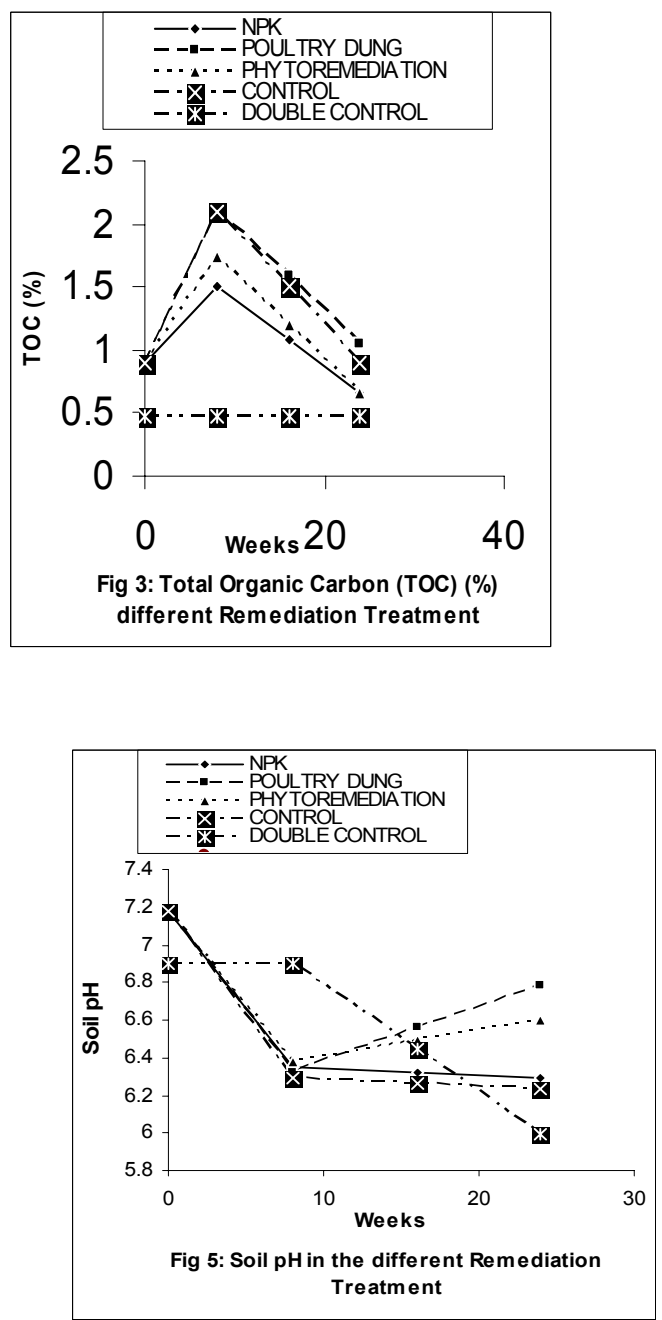

There was no significant difference between the various remediation treatments for soil $\mathrm{pH}$, Zinc and Copper (Figures 5, 6 and 7). This range of $\mathrm{pH}$ favoured oil degradation by microorganisms as observed on similar studies that $\mathrm{pH}$ range of 6-9 provides better conditions for mineralization of hydrocarbons since most bacteria capable of metabolizing hydrocarbons develop best at $\mathrm{pH}$ condition close to neutrality (Atlas \& Bartha, 1992; Manuel et al., 1993). The low and non-significant level of Zinc and Copper is an indication of nontoxicity of the heavy metals in the polluted soils. to the Nitrogen fixed, the plant (Vigna sp) also provide root exudates of carbon, energy, nutrient, enzymes and sometimes oxygen to microbial population (Campbell, 1996; Cunningham et al., 1996; Vance, 1996) thereby stimulating the biodegradation activities (Gunther et al., 1996; Atlas \& Bartha, 1998).
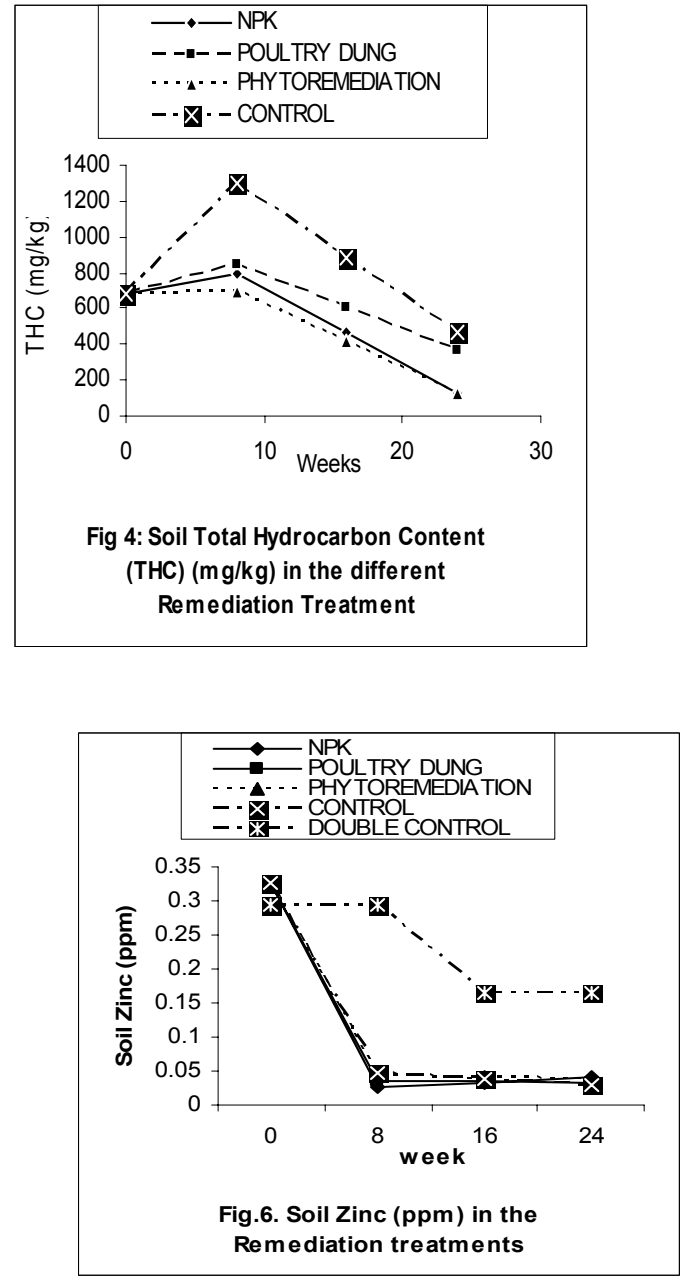

Fig. 8 indicated that carbon- Nitrogen $(\mathrm{C} / \mathrm{N})$ ratios were significantly reduced in all the treatments. Highest reduction was recorded in the NPK treatment. The fact that lower $\mathrm{C} / \mathrm{N}$ ratio were recorded for the treatment supplied with inorganic fertilizer indicated that some nutrients were lacking (Odokuma \& Dickson, 2003). This meant that hydrocarbon degradation and loss increased with smaller $\mathrm{C} / \mathrm{N}$ ratios justifying the use of nitrogenous nutrient sources to aid biodegradation.

* Corresponding author: Tanee, F. B. G. 


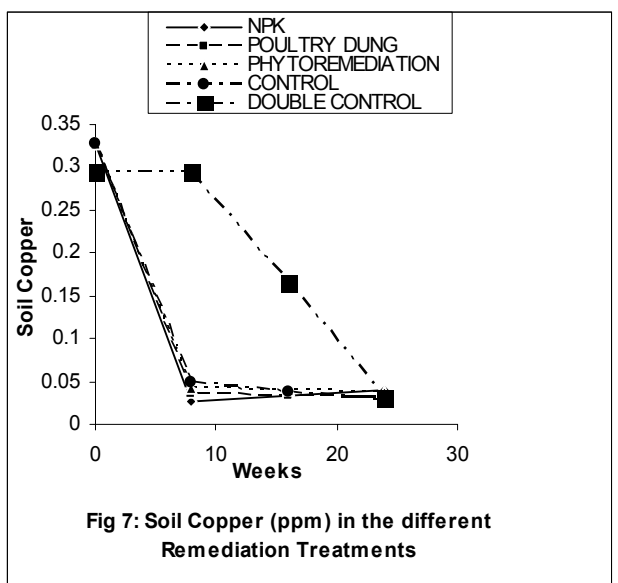

Conclusion: In conclusion, biostimulation (inorganic and organic fertilizer) and phytoremediation (Vigna sp) had the tendencies in stimulating oil biodegradation process, indicating that they are good remediation treatment option in crude oil polluted soil. The fact that option A (inorganic fertilizer) has the highest hydrocarbon loss and highest nutrient content than the other treatment options indicated that it is a prefer remedial measure followed by phytoremediation while organic manure (poultry dung) proved to be the least effective for crude oil bioremediation.

\section{REFERENCES}

Alexander S.K; Webb, J.W. (1987). Relationship of Spartina alterniflora growth to sediment oil content following an oil spill. Proceedings of 1987.International Oil Spill Conference. America Petroleum Institute. Washington DC. Pp 445-449.

Atlas, R.M; Bartha, R. (1992). Hydrocarbon biodegradation and oil spill bioremediation. $A d v$. Microb. Ecol. 12: 287-338.

Atlas, R.M; Bartha, R. (1998). Microbial Ecology: Fundamental and Applications. Benjamin/Cumming Publishing Company. Inc. Don Mill, ON.

Bragg, J.R., Prince, E.J., Harner; Atlas, R.M. (1994). Effectiveness of bioremediation for the Exxon Valdez oil spill. Nature.368: 413-418.

Campbell, R. (1985). Plant Microbiology. Edward Arnold, Baltimore, M.D.

Cunningham, S.D., Anderson, T.A., Schwab, A.P; Hsu, F.C. (1996). Phytoremediation of soils

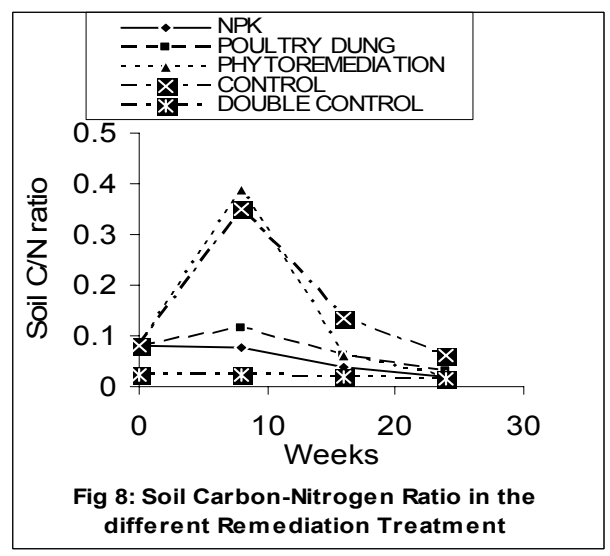

contaminated with organic pollutants. Advances in Agronomy. 56: 55-114.

Ellis, R., Balba, M.J; Theile, P. (1990). Bioremediation of oil contaminated land. Journal of Environ. Technology. 11: 443-454.

Gudin, C; Syrath, W. J. (1975). Biological aspect of land rehabilitation following hydrocarbon contamination. Environmental Pollution 8:107112.

Gunther, T., Dornberger, U; Fritsche, W. (1996). Effects of ryegrass on biodegradation of hydrocarbon in soil. Chemosphere 33(2): 203215.

Kinako, P.D.S. (1988). Fundamentals of Quantitative and Applied Plants Ecology. Belk Publishers, Port Harcourt.

Lee, K; Tremblay, G.H. (1993). Bioremediation: application of slow release fertilizers on low energy shorelines. Proceedings of the 1993 Oil Spill Conference. American Petroleum Institute, Washington DC.

Lee, K., Tremblay, G.H; Cobanli, S.E. (1995). Bioremediation of oil beach sediments: Assessment of inorganic and organic fertilizers. Proceedings of 1995 Oil Spill Conference. American Petroleum Institute, Washington DC.

Manuel, C., Jorge, R; Maximilliano, C. (1993). Biodegradation experiment conducted at a tropical site in Eastern Venezuela. Waste Mgt \& Res. 11: 97-106.

NLNG (Nigeria Liquified Natural Gas) (1995). Environmental Impact Assessment Report. Vol.10. 
Odokuma, L.O; Ibor, M.N. (2002). Nitrogen fixing bacteria enhanced bioremediation of a crude oil polluted soil. Global Journal of Pure and Applied Science. 8 (4): 455-468.

Odokuma, L.O; Dickson, A.A. (2003). Bioremediation of a crude oil polluted tropical Mangrove Environment. Journal of Applied Sciences and Environmental Management. 7: 2329.

Okpokwasili, G.C; Amanchukwu S.C. (1988). Petroleum hydrocarbon degradation by Candida species. Environ. Int. 14:243-247.

Pezeshki, S.R., Hester, M.W., Lin, Q; Nyman, J.A. (2000). The effects of oil spill and clean-up on dominant US Gulf coast marsh microphytes: a review. Environmental Pollution. 108:129-139.
Stewart, E.A., Grimshaw, H.M., Parkinson, J.A; Quarmby, C. (1974). Chemical Analysis of Ecological Materials. Blackwell Publications. London.

Vance, D.B. (1996) Phytoremediation: enhancing natural attenuation processes. National Environmental Journal 6: 30 - 31 .

Venosa, A.D; Zhu, X (2002). Guidance for the bioremediation of oil - contaminated wetlands, marshes and marine shorelines. In :Fingerman, M; Nagabhushanam, R. (eds) Bioremediation of Aquatic and Terrestrial Ecosystems. Science Publishers. U.K. Pp. $142-171$. 